\title{
THEORETICAL ASPECTS OF THE STUDY OF CORPORATE ETHICS
}

\author{
Oksana Korolovych \\ Department of Accounting, Taxation, and Marketing, Mukachevo State \\ University, Mukachevo, Ukraine
}

CMESTE

JEL Category: F65, G23, G28, H63, 016

\begin{abstract}
The article examines some approaches to the understanding of the concept of corporate ethics. The author interprets corporate ethics as a set of moral principles and standards of corporate relations. Corporate ethics is the key element that unites all members of the corporation in a single social organism. Corporate ethics acts as a form of social consciousness inherent in both entrepreneurs and employees who share common goals of their professional activities. It is a non-economic factor having an effective impact on corporation activities. The author analyzes why large organizations characterized by anonymous relations (corporations) establish ethical regulation with all its structural elements (code, ethical committees, etc.). The author makes a distinction between the direct immediate duties of the employee and his/her discretionary duties. Corporate ethics does not hinder efficiency, and it can inspire workers to achieve the organization's main goal. Also, corporate ethics implements in the corporation such functions as the function of protecting the moral prestige of the corporation, the function of defending the interests of members of the corporation, the function of coordinating competing interests, the ambitions of the members of the corporation to ensure cohesion, unity of the group. The implementation of the above functions of corporate ethics can be a competitive advantage for the organization. The author concludes that it is important for the organization to create such a system of moral regulation (structures, institutions) that motivate employees to act morally, in which it would be beneficial to be socially responsible, but that would simultaneously take into account and protect the interests of workers.
\end{abstract}

Keywords: Corporate ethics; corporation; moral regulation of relations; corporate ethos.

\section{STUDY}

At the end of the twentieth century, important changes took place in the economies of developed countries, which entailed essential changes in corporate governance. In the theory of management, for a long time, the understanding

The address of the author: Oksana Korolovych 恝oxyk_k@yahoo.com of the competitiveness of an enterprise, associated exclusively with its economic efficiency, that is, whether the company is capable of making large profits, was leading. This understanding of the main goal of the organization was outlined in the $18^{\text {th }}$ century by $A$. Smith in The Wealth of Nations, as well as in the late $19^{\text {th }}$ and early $20^{\text {th }}$ centuries in the works of $F$. Taylor and G. Ford. During the twentieth century, various techniques (approaches) have been formed in the management of organizations. For example, in 
scientific management, they tried to destroy informal relations between team members, but when this turned out to be impossible, a new way was opened in the theory of human relations - to organize, not destroy informality. The result of these approaches in Western economies has become a hierarchical, vertically integrated large industrial corporation. The dominant spheres of management in such a corporation were the issues of rational organization of the organization, finance, and production technology.

With the development of technologies, the growth of competition, the increasing requirements of consumers, the nature of the external and internal environment of the enterprise begins to change. A modern enterprise is now forced to consider not only the external but also the internal environment, not only the requirements of consumers but also the needs and dignity of employees. Today, there is an increasingly active and obvious break away from the purely economic motivation of human activity (Ageev, 2011). Labor relations are becoming an integral part of the corporate culture. An enterprise forms a specific form of culture corporate culture, which can be defined as a community of values, norms, expectations that are stable for a given organization, which determine the behavior of its team members. For quite a long time, the axiological components in the motivation of an employee's work activity were assessed as a secondary resource, and the creation of a cultural environment in an organization was more often spontaneous, although the attention to organizational culture on the part of managers and researchers was constantly increasing. But, starting from the $80 \mathrm{~s}-90 \mathrm{~s}$ of the last century, the influence on the cultural elements of the organization's life becomes continuous, being, for the most part, a well-coordinated strategy of the company's management to form corporate ethics (Kuznetsov, 2003).

Thus, it can be noted that recently there has been a significant increase in interest in corporate ethics issues not only of scientists but also of business representatives. Strengthening the role of corporate ethics in management and the system of modern economic relations determined the relevance of the topic of this work.

Corporation translated from English corporation, from lat. corporiu - association, community) means a society, union, group of persons united by a community of professional or class interests (Avdasheva, S., et al., 2008). At the same time, the understanding of the corporation in a broad and narrow sense should be distinguished. So, in a broad sense, a corporation is an association of people to perform a task. In the narrow sense, "a corporation is large enterprises and their associations, in which business entities voluntarily combined their resources (financial, real estate, information, labor, ability to innovative risky activities, etc.) into consolidated capital and created an economic system based on free division and labor cooperation, the general strategy of entrepreneurship to sustainably generate entrepreneurial income" (Inozemtsev, 2007). The most important difference between a corporation and other forms of collective activity is "the formation of a so-called legal entity, that is, such entity that does not exist physically, but which at the same time can carry out actions, appear in court, own and manage property" (Inozemtsev, 2007). Also, the owners of the corporation (shareholders) are most often separated from operational management, but the corporation is run by professional managers.

Within the framework of this topic, it is important to understand that a corporation is a form of organizing industrial relations that also presupposes a new form of cooperation - largely anonymous relations. If in small companies the relationship is quite transparent and rather personal, in large corporations, employees most often do not know each other personally, personal management is replaced by rules and organizational structures. It is in corporations as large organizations that regulation is established, which is called ethical, with all the relevant infrastructure, codes, committees, etc. Only this way of streamlining relations can direct the behavior of a large number of people working in one company into a unified channel, contribute to the creation of a single organizational culture. In small collectives, codes are optional, here everyone knows each other personally, they can agree, here the norms of personal morality and the morality of interpersonal relations are applied.

Corporations present themselves as transparent organizations. Corporations are closed organizations, the so-called "states within a state," which do not allow interfering in their internal life" 
(Kunda, 1992). The degree of disclosure of information (financial, commercial, etc.) is strictly regulated. Thus, financial information is disclosed strictly by national and international standards, and relationships within the organization and interaction with external partners, the specifics of company management, which allow achieving greater efficiency, are most often classified as commercial secrets. According to the National Corporate Governance Report, corporations prefer to classify most information about themselves and their activities as trade secrets.

Relations in the corporation are structured vertically, strictly hierarchically. Corporate relations are characterized by a strict internal order, a clear distribution of functions and rules of conduct, regulated by administrative and service documents, as well as strictly defined powers, responsibility, and reporting (each employee knows what for and to whom he/she is accountable).

Moral relations in organizations (corporate ethos) are relations that develop between employees in the process of joint activities to achieve a common goal. Some authors divide moral obligations arising in business relations into direct (immediate) and discretionary (from the Latin "discretio" - "separation", "difference"; discretionary - left to one's discretion). Direct duties are the obligation to perform the functions that a person assumes when hiring, these are the duties that are spelled out in the employment contract. By signing an employment contract or job descriptions, the employee thus agrees to the terms of the organization and promises to perform his/her functions. Special services monitor the fulfillment of direct duties by the employee. In case of violation by an employee of his/her direct, immediate, duties, certain sanctions are applied to him/her (bringing to administrative responsibility, fines, in some, especially egregious cases, dismissal, or criminal prosecution). Discretionary duties are actions that are performed by an employee voluntarily (for example, helping a coworker, training newcomers, participating in the public life of the organization, etc.). Performing discretionary duties improves the morale and psychological atmosphere in the team, while if employees do not fulfill their immediate responsibilities, the organization's activities will cease. Therefore, in case of conflict between direct and discretionary duties, preference should be given to the direct duties of the employee.

The relationship between employees in an organization is governed by law, morality, administrative, and other social norms. Communication, direct interaction of partners, is governed primarily by the norms of morality and etiquette. One of the main tasks of the moral regulation of relations in a corporation is to create harmonious relations between employees based on agreement and mutual understanding. The most important goal of moral regulation is justice, which ensures social peace and the satisfaction of the legitimate interests of everyone.

Corporate ethics is a special way of regulating relations in corporations. (It should be noted that E. Durkheim was the first to pay special attention to the role of moral regulation in corporations and described it. Durkheim makes a great contribution to the study of forms of collectivity, developing the idea of creating professional corporations as new elements of social solidarity. According to the sociologist, the main structural element of future society will become a corporation that can act as a collective person (since the corporation is composed of individuals whose interests are in solidarity), being a certain "moral environment" for its members. According to E. Durkheim, the corporation should take on a wide range of social functions (from production to moral and cultural)). The concept of "corporate ethics" in a narrow sense appears relatively recently, in the theory of the so-called "cultural management" (for the first time they started talking about the culture of organizations as a new perspective of their consideration in the 70 s of the XX century, but, to be more precise, the research of corporate ethics itself appeared in the United States only in the 80s and 90s). The main idea of this approach is to use the moral potential of the organization to create a cohesive organizational culture, to better integrate employees into this culture, to make them more interested in the results of the organization's work and thereby make the organization more efficient and competitive. An example of "cultural management" was the Japanese organizational culture, which was associated with the outstanding economic success of Japan in the 60s and 80 s of the XX century. These ideas were supposed to be implemented based on the Western economy. 
In modern literature, there are not many definitions of the concept of "corporate ethics", and in general they do not contradict each other. "Corporate ethics in the broadest sense of the word is understood as a system of universal and specific moral requirements, and norms of behavior, implemented in the process of functioning of corporate structures." Or "Corporate ethics (Latin ethica - custom, character) is a system of norms of moral corporate behavior of management, personnel within the corporation-community and in relations with representatives of the external environment" (Kochetkoov \& Supyan, 2005). In most foreign sources, the term "corporate ethics" is identical to the terms "business ethics" and "organizational ethics (organization ethics)" (Entine, 1996). Here is the definition of the terms "organizational ethics" and "business ethics", which the American Wikipedia (2020B) gives: "Organizational ethics expresses the values of the organization concerning its employees and/or other objects, regardless of state and/or regulatory laws"; "Business ethics - (also known as corporate ethics) is a form of applied ethics or professional ethics that addresses ethical principles and moral and ethical issues that arise in the business environment. It applies to all aspects of business behavior and relates to the behavior of individuals and business organizations in general" (Wikipedia, 2020A). Note that the definition of the term "business ethics" given above is rather confusing: it is business ethics and corporate and professional. However, it can be noted that such confusion can serve as proof that the topic "corporate ethics" is new and insufficiently developed for both Ukrainian and foreign science. Also, it can be noted that in the English-language literature the concepts of "corporate ethics", "business ethics", "organizational ethics" are interchangeable.

The meanings in which the term "corporate ethics" is used should be clarified. First, in everyday speech and non-specialized literature, corporate ethics is understood as the compliance of intraorganizational relations with high moral standards or these standards themselves. Second, in a broad sense, corporate ethics is understood as organizational ethics. Third, from the point of view of management theory, corporate ethics is a tool for regulating moral relations in large organizations with anonymous relations (corporations). And, finally, fourth, corporate ethics is a discipline of applied ethics that studies the mechanism of regulating moral relations in large organizations (corporations).

Corporate ethics is institutional ethics. Institutions "are more than individual norms (conventions, laws); they are, as it were, a bundle of such norms, cultural and social structures with the goal of longterm regulation and normalization of certain social relations, which are repeated as the main processes of social life and therefore require a certain stabilization... Thus, institutions are normative structures that normalize the repetitive events in social life, asserting them for a long time. They set boundaries for individuals and set orientation thus imparting a certain regularity and confidence to the coexistence of people" (Kunda, 1992).

The decisive factor in corporate morality is not personal morality, but objectified moral values and norms of the organization. The compliance of the employee's actions with these corporate norms should be guaranteed "not by external command and control "from above", but by ensuring (modeling and constructing in practice) such circumstances in which the individual himself/herself wants to act according to the generally accepted norms and principles in the organization" corresponding to the values of this corporation. These norms and principles, corporate values should be able to change the behavior of employees and should shape socially desirable behavior.

It should be noted that the attitude towards corporate ethics is rather ambiguous. In the past two decades, there has been a fair amount of critical research, one way or another affecting corporate ethics. For example, K. Gray in his work "Organizations. Theories, conflicts, and managers" believes that in many ways "cultural management" touches upon a serious problem since the subject changing, in this case, is "not work, but an employee". The scientist believes that corporate culture is created and managed by managers to increase labor productivity. "Cultural management seeks to intervene and control a person so that there is no distance between his/her personal goals and the goals of the organization" (Prokof'ev, 2009). Thus, the employees of the organization must have such 
goals and values that are directed towards the goals of productivity, or quality, or quantity, that is, the profit of the company. These should be shared values, that is, the employee must sincerely adhere to them, otherwise he/she will be fired.

According to K. Gray, the main problem is to find and form such cultural values that would meet the goals of not only the corporation but also the employee. However, more often "values", notes K. Gray, are formed "from above", by a small group of managers and are not shared by employees. The employee has a dilemma - either adapt or quit. The challenge for a manager is maintaining the necessary culture, with oversight and control being the most common use. The conclusion that K. Gray makes, relying on some research, for example, on the research of $\mathrm{H}$. Wilmot, is that culture is not so easy to manage (cultural management should be taken seriously), that a culture is a special form of control, the task of which is "not external regulation of the behavior of workers, but the formation of their inner world and identity".

In general, speaking of cultural management, Gray emphasizes that culture is directly related to the development of self-governing and selfdisciplined people".

But more common are studies in which opinion prevails about the advantages of a corporation, which cares about the moral component of its activities, where there are several arguments for the "supposed payback of ethics":

1. the ethical reputation of the corporation is quite attractive to investors and partners.

2. socially responsible activity and the implementation of general and professional and ethical standards by the corporation's managers reduce financially and image losses from sanctions imposed by the state.

3. compliance with ethical standards by employees of all levels reduces financial losses associated with negligence and fraud, reduces the cost of personnel supervision, and also eliminates some difficulties for coordinated joint activities to achieve the economic goals of the company (Landa, 1993). Based on these arguments, the author of the article concludes that corporate ethics helps to preserve the company's reputation and gives advantages in organizing activities.

However, a problem arises - with this approach morality becomes not a goal but a means. That is, when introducing ethical programs, company managers begin to treat moral principles not as external restrictions on their activities, but as one of the means of making a profit. Besides, for management, morality can act in a dual capacity: on the one hand, as an instrument of corporate governance (since the manager creates corporate institutions, controls, and regulates their implementation), on the other, as an intrinsic moral guideline (since the manager is a member of the team himself/herself). Based on the research of social psychologists, it can be stated that this situation can lead to the fact that the higher the position of a manager in the corporate hierarchy, the more inclined he/she is to moral hypocrisy, to the presentation of stricter moral requirements to others and more loyal to himself/herself (Sutor, 2001).

According to many modern researchers, corporate ethics not only does not interfere with efficiency but can also inspire employees to achieve the main goal of the organization. Besides, corporate ethics in the corporation implements such functions as the function of protecting the moral prestige of the corporation, the function of protecting the interests of the members of the corporation, the function of coordinating competing interests, the ambitions of the members of the corporation to ensure cohesion and unity of the group. Implementation of the above functions of corporate ethics can be a competitive advantage of the organization. Summing up, we can conclude that it is important for an organization to create a system of moral regulation (structures, institutions) that would motivate employees to act morally, in which it would be beneficial to be socially responsible and it would be risky not to be, but which would simultaneously take into account and protect the interests of employees. 


\section{WORKS CITED}

Ageev A.I. (2011) Predprinimatel'stvo: problemy sobstvennosti i kul'tury [Entrepreneurship: problems of property and culture]. Moscow: Nauka Publ.

Avdasheva, S., et al. (2008). Natsional'nyi doklad po korporativnomu upravleniyu [National report on corporate governance], vol. 1 (2008). Moscow.

Entine J. (1996). Corporate ethics and accountability. Corporate governance. Available at: http://www. corpgov.net/forums/commentary/entine1.html [Accessed 14/02/2017].

Inozemtsev V.(2007) Tvorcheskie nachala sovremennoi korporatsii [Creative foundations of a modern corporation]. Mezhdunarodnaya ekonomika i mezhdunarodnye otnosheniya [International economics and international relations], 11, pp. 18-30.

Kochetkov G.B., Supyan V.B. (2005) Korporatsiya: amerikanskaya model' [Corporation: American model]. Saint Petersburg: Piter Publ.

Kunda G. (1992) Engineering culture. Control and commitment in a high-tech corporation. Philadelphia: Temple University Press.

Kuznetsov I.N. (2003) Korporativnaya etika [Corporate ethics]. Moscow.

Landa M.N. (comp.) (1993) Sovremennyi slovar' inostrannykh slov [A modern dictionary of foreign words]. Moscow: Russkii yazyk Publ.

Prokof'ev A.V. (2009) Aspekty praktichnosti morali [Aspects of practicality of morals]. In: Bakshtanovskii V.I., Karnaukhov N.N. (eds) Paradigmy prikladnoi etiki. Vedomosti. Vyp. 35 [Paradigms of applied ethics]. Tyumen, pp. 52-69.

Sutor B. (2001) Malaya politicheskaya etika [Small political ethics]. In: Politicheskaya $i$ ekonomicheskaya etika [Political and economic ethics]. Moscow: Fair-Press, pp. 27-174

Wikipedia. (2020A). Business ethics. Retrieved from : https://en.wikipedia.org/wiki/Business_ethics. [Accessed 12/02/2020].

Wikipedia. (2020B). Organizational ethics. Retrieved from : http://en.wikipedia.org/wiki/Organizational_ ethics [Accessed 12/02/2020].

Received for publication: $\quad 07.09 .2020$

Revision received: $\quad 22.09 .2020$

Accepted for publication: $\quad 30.12 .2020$

\section{How to cite this article?}

Style - APA Sixth Edition:

Korolovych, O. (2021, January 15). Theoretical aspects of the study of corporate ethics. (Z. Cekerevac, Ed.) MEST Journal, 9(1), 54-60. doi:10.12709/mest.09.09.01.07

Style - Chicago Sixteenth Edition:

Korolovych, Oksana. 2021. "Theoretical aspects of the study of corporate ethics." Edited by Zoran Cekerevac. MEST Journal (MESTE) 9 (1): 54-60. doi:10.12709/mest.09.09.01.07.

Style - GOST Name Sort:

Korolovych Oksana Theoretical aspects to the study of corporate ethics [Journal] // MEST Journal / ed. Cekerevac Zoran. - Belgrade - Toronto : MESTE, January 15, 2021. - 1 : Vol. 9. - pp. 54-60. 
Style - Harvard Anglia:

Korolovych, O., 2021. Theoretical aspects of the study of corporate ethics. MEST Journal, 15 January, 9(1), pp. 54-60.

Style - ISO 690 Numerical Reference:

Theoretical aspects of the study of corporate ethics. Korolovych, Oksana. [ed.] Zoran Cekerevac. 1, Belgrade - Toronto : MESTE, January 15, 2021, MEST Journal, Vol. 9, pp. 54-60. 